\title{
"The mediating effect of investment decisions and financing decisions on the effect of corporate risk and dividend policy against corporate value"
}

\begin{tabular}{|c|c|c|}
\hline AUTHORS & \multicolumn{2}{|l|}{ Yulia Efni } \\
\hline ARTICLE INFO & \multicolumn{2}{|c|}{$\begin{array}{l}\text { Yulia Efni (2017). The mediating effect of investment decisions and financing } \\
\text { decisions on the effect of corporate risk and dividend policy against corporate } \\
\text { value. Investment Management and Financial Innovations, 14(2), 27-37. } \\
\text { doi:10.21511/imfi.14(2).2017.03 }\end{array}$} \\
\hline DOI & \multicolumn{2}{|c|}{ http://dx.doi.org/10.21511/imfi.14(2).2017.03 } \\
\hline RELEASED ON & \multicolumn{2}{|l|}{ Friday, 02 June 2017} \\
\hline RECEIVED ON & \multicolumn{2}{|l|}{ Friday, 24 February 2017} \\
\hline ACCEPTED ON & \multicolumn{2}{|l|}{ Thursday, 23 March 2017} \\
\hline & \multicolumn{2}{|l|}{$($ (c) ) EY-NC } \\
\hline LICENSE & \multicolumn{2}{|c|}{$\begin{array}{l}\text { This work is licensed under a Creative Commons Attribution-NonCommercial } 4.0 \\
\text { International License }\end{array}$} \\
\hline JOURNAL & \multicolumn{2}{|c|}{ "Investment Management and Financial Innovations" } \\
\hline ISSN PRINT & \multicolumn{2}{|l|}{$1810-4967$} \\
\hline ISSN ONLINE & \multicolumn{2}{|l|}{$1812-9358$} \\
\hline PUBLISHER & \multicolumn{2}{|c|}{ LLC "Consulting Publishing Company "Business Perspectives" } \\
\hline FOUNDER & \multicolumn{2}{|c|}{ LLC “Consulting Publishing Company "Business Perspectives" } \\
\hline \multirow[b]{2}{*}{ NUMBER OF REFERENCES } & & 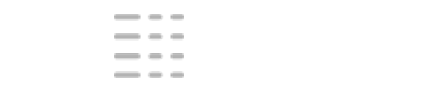 \\
\hline & NUMBER OF FIGURES & NUMBER OF TABLES \\
\hline 18 & 7 & 3 \\
\hline
\end{tabular}

(C) The author(s) 2023. This publication is an open access article. 


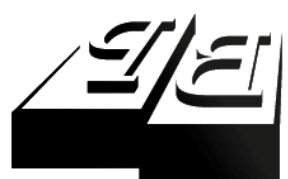

BUSINESS PERSPECTIVES

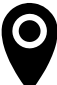

LLC "CPC "Business Perspectives” Hryhorii Skovoroda lane, 10, Sumy, 40022, Ukraine

www.businessperspectives.org

Received on: $24^{\text {th }}$ of February, 2017 Accepted on: $23^{\text {th }}$ of March, 2017

(C) Yulia Efni, 2017

Yulia Efni, Department of Management, Faculty of Economy, University of Riau, Indonesia.

\section{THE MEDIATING EFFECT OF INVESTMENT DECISIONS AND FINANCING DECISIONS ON THE EFFECT OF CORPORATE RISK AND DIVIDEND POLICY AGAINST CORPORATE VALUE}

\begin{abstract}
This study aims to determine the effect of mediation decisions on investment, and financing decisions influence the company's risk and dividend policy on firm value. The unit of analysis in this research is company property and real estate sectors listed in Indonesia Stock Exchange continuously for 9 years (2001-2008) that have a complete financial report on the study period. This research study using descriptive analysis and inferentsial to prove examine the relationship between the study variables with the five structural models using WarpPLS. This study is basically to analyze the patterns of relationships between variables in order to determine the effect of directly or indirectly, a set of independent variables (exogenous) to the dependent variable (endogenous). The company's risk and investment decisions are able to increase the value of the company, while the dividend policy and funding decisions are not able to increase the value of the company, the study was conducted at the companies in the sectors of property and real estate, then this study better developed for other sectors that have different characteristics. Originality from this research is the populations in this study were the companies in the sectors of property and real estate with specific criteria Indonesia and the data used in this study were secondary data obtained from the Indonesia Stock Exchange in the form of financial statements.
\end{abstract}

Keywords

investment decision, financial decision, corporate risk, dividend policy

JEL Classification $\quad$ H12, E52, G31

\section{INTRODUCTION}

The monetary crisis in 1999 in Indonesia triggered by the depreciation of the rupiah against the dollar has a major effect on the business world activities, especially the sectors of property and real estate. The increase in interest rates that affects the activities in the sectors of property and real estate is also in line with the increase in housing loan rates. In addition, tight monetary policies implemented by the government make companies suffer a liquidity crisis.

Nurdin (1999) states that the go-public companies in the sectors of property and real estate mostly use short-term loans from abroad that are used for long-term financing like projects building, so that many companies experience financial difficulties. Error in determining financing decisions poses a risk to the company and many developers must give their collateral to the bank at the financial crisis. However, after the financial crisis, i.e. about 2003-2007, financing pattern of the developers had changed. They 
prefer to use their own capital and the products sales results which had begun since preselling (Handaka, Kompas October 27, 2008). This change in financing pattern showed that companies in the sectors of property and real estate become more careful in the financing of investment which leads to the risks that arise for the companies and further affect the corporate value.

Like investing in the sector of manufacturing industry, investing in the sectors of property and real estate should consider two things: the return of the investment and the risk borne for investing in the sector. Investors expect a higher return on their investments compared to the risks they will bear. A high return affects the performance of companies, so that it affects the company's stock price. The stock price reflects the value of the company as Van Horne (2002) says, that the value of the company is reflected in the company's stock market price.

Based on the viewpoint of financial management, the company's goal is to maximize stockholders' prosperity. The increase in stockholders' prosperity can be achieved through the increase in the company's value. According to Jensen (2001) in Stakeholder Theory, he suggests that maximizing the corporate value is a trade-off of the maximum corporate value received by the stakeholders in the long term.

Investment decision is one of the factors that affects the corporate value, in which the investment decision is associated with the decisions about the allocation of funds, in terms of sources of financing (which come from inside and outside the company) as well as the use of funds for the short-term and long-term purposes. According to Husnan (2000), the goal of the company's investment decisions is to maximize Net Present Value (NPV) as a positive NPV would increase the real assets. The real assets have noticed the time value of money, means that the company's assets could be improved if the investment decisions can produce a positive NPV so that will impact on the corporate value. This was confirmed by the research findings of Fama (1978) which state that investment decisions only determine the corporate value.

Risks in financial management can be divided into systematic risk and unsystematic risk. Systematic risk is the risk that cannot be controlled by the company but experienced by all companies in a country, as the current global crisis that is impacting the decline in the company's stock price index. While unsystematic risk is the risk that can be controlled by the company. This risk relates to the ability of management to manage the company mainly linked to the decisions, i.e. decisions in investment, financing, and dividend policy. Systematic risk and unsystematic risk have a relationship with the corporate value.

Like investment decisions, research on financing decisions has an impact on the risk that is still in the concept of theory. It is assessed on trade-off theory, i.e. the greater the debt, the higher the possibility of bankruptcy, because the higher the debt, the greater the interest to be paid. The greater the possibility of not paying interest and the lenders could make bankruptcy which in turn causes the corporate value decreases. The implication of this trade-off theory is the manager will think between the tax savings and the bankruptcy costs arising from the debt, which, in turn, affects the corporate value.

Based on portfolio theory and the capital asset pricing model, it can be said that risk is an important factor in investment decisions making. Risk is also considered in financing decisions making and dividend policy as errors in financing decision making and dividend policy pose a risk to the company, which in turn affect the corporate value. This is consistent with the trade-off theory where the greater the debt, the greater the possibility of not paying the interest and the more likely the company becomes insolvent. Likewise, the bird in the hand theory which states that high dividend payment aims to reduce uncertainty for investors so that it will reduce the risk which in turn affects the value of the company. Based on the background above, the study aimed to test the Mediating Effect of Investment Decisions and Financing Decisions on the Effect of Corporate Risk and Dividend Policy against Corporate Value. 


\section{LITERATURE REVIEW}

The purpose of financial management is to maximize the corporate value, in which the objective is associated with three financial decisions of companies, i.e. investment, financing, and dividend decisions. It is in accordance with the three principles in financial management proposed by Damodaran (2006), i.e. investment principle, financing priciple and dividend principle, in which the three principles are the main principles in corporate finance. Damodaran (2006) also states that when making investment, financing and dividend decisions, the corporate finance looked at the three decisions as some things separated in achieving the final goal, i.e. maximizing the corporate value. Consequently, every decision either investment, financing, or dividend policy which can increase the corporate value is considered to be good.

Martono (2001) suggests that investment is defined as company's capital investment. Investment can be made in real assets or financial assets. Investment decision is a decision on the assets managed by the company. Investment decision directly affects the amount of investment profitability and cash flow of the company in the future.

Investment decision is an important decision from the three decisions in financial management since investment decision directly affects the amount of investment profitability and cash flow of the company in the future. Capital budgeting is an investment decision on the allocation of funds to the various investment proposals whose benefits will be obtained in the future. According to Riyanto (2001), investment decision is related to the determination of the overall number of assets in the company, the composition of the assets as well as the risks of the business.

As well as investment decisions, the goal of obtaining a positive NPV that would increase the corporate value can be used in financing decisions making. This is in accordance with the financing principle proposed by Damodaran (2006) which states that the financing principle is to manage the use of the financing mix in financing the investment made. The options of financing mix (debt and equity) maximize the value of the investment made and the financing associated with the form of asset financed.
Hanafi (2005) explains that the purpose of financing decisions is to obtain funds with the cheapest cost. Financing includes short-term and longterm financing, in which short-term financing is defined as less than one year of financing, while the long-term financing is over a period of business. Husnan (2000) says that the financing decisions and dividend policy are reflected on the position of the liabilities of the company. If we only pay attention to the funds embedded in the long-term, then the ratio is referred to the capital structure, while when considering in both short-term and long-term, the ratio is called the financial structure. Financing decisions and dividend policy will affect both the two structures.

\section{METHODOLOGY}

The respondets in this study were the companies in the sectors of property and real estate that meet the criteria:

1. Listed in Indonesia Stock Exchange continuously for 9 years (2001-2008), means that the companies had never experienced a delisting in the study period.

2. Having a complete financial report on the study period.

3. From the 48 companies listed in the Indonesia Stock Exchange, a total of 31 companies were qualified as members of the study sample.

The data used in this study were secondary data obtained from the Indonesia Stock Exchange in the form of financial statements. The data of financial statements used were the balance sheets and income statements ended on December 31. The financial statements were sourced from ICMD (2010), ICMD (2008), ICMD (2005), ICMD (2003) and Jakarta Monthly (2000 to 2010).

This study used descriptive and inferential analysis to prove and examine the relationship among the five study variables with structural model using WarpPLS. This study was basically aimed to analyze the pattern of relationship among variables to determine the direct or indirect effect of a set of exogenous variables on the endogenous variables. 


\section{RESEARCH RESULT}

Descriptive analysis. In this study there are 5 variables: Risk company, dividend policy, Investment decisions, financing decision, and corporate values. Descriptive analysis is described as follows:

Corporate risk. Risk is the probability of not achieving the expected profit rates or the possibility of return received that deviates from the expected return because of decisions taken by the company manager. The risk that arises can be reflected in the indicators of business risk, market risk and financial risk. The development of the average risk indicators can be seen in Figure 1.

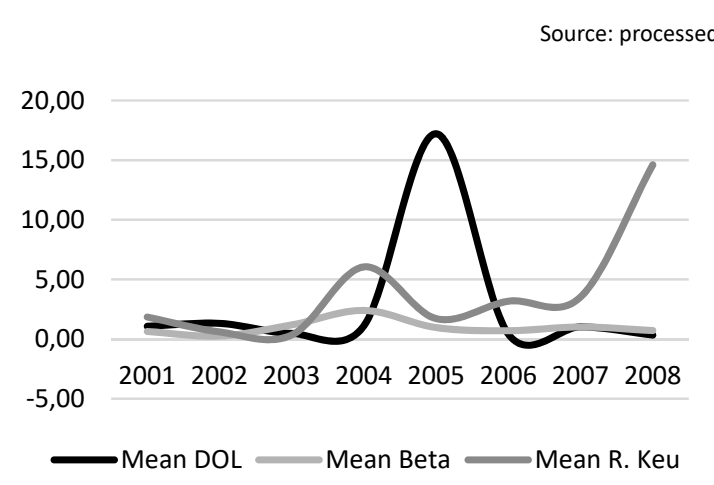

Figure 1. Development of average. Average Value Risk Indicators in Sector Property and Real Estate Year during 2001-2008

Figure 1 shows that the average value of Degree Operating Leverage fluctuates, where the average value of the lowest Degree Operating Leverage was 0.34 in 2008, while the average value of the highest Degree Operating Leverage in 2005 was 17.22. While the beta average value fluctuates where the lowest average stock beta value in 2002 was 0.26 . The higher the stock beta, the higher the market will face the risk. While the highest average stock beta value was 2.40 in 2004. This was due to the general election which affected the company's stock price resulted in the increased risk.

The highest average value is the financial risk but based on loading factor in the Table 1, financial risk is not included in subsequent analysis since the risk components weight has opposite signs with the two other components. However, based on the average, the highest financial risk, i.e. 3.98 means that the use of debt will result in an increase of risk for the company. Based on the Table 1, company's operating risk (DOL) and market risk (beta) have the same loading value, i.e. 0.707 , which means that the operating risk and market risk have the same contribution in increasing the risk for the companies in the sectors of property and real estate. When associated to an average value between the operating risk and the market value, then the operating risk has a high average of 2.87, which means that when associated with the loading factor, then the high operating risk will increase the risk of the company and affect the corporate value.

Table 1. Measurement model

\begin{tabular}{|c|c|c|}
\hline Variables & Indicators & $\begin{array}{c}\text { Loading/ } \\
\text { Weight }\end{array}$ \\
\hline \multirow{4}{*}{ Investment Decision } & MBAR & 0.610 \\
\hline & CAP.BVA & 0.545 \\
\hline & CATAR & 0.548 \\
\hline & MVE.BE & 0.638 \\
\hline \multirow{2}{*}{ Funding Decision } & SDTBV & -0.944 \\
\hline & DTA & -0.944 \\
\hline \multirow{2}{*}{ Divident Policy } & Deviden Yield & 0.794 \\
\hline & DPR & 0.794 \\
\hline \multirow{2}{*}{ Company Risk } & $\mathrm{DOL}$ & 0.707 \\
\hline & BETA.SHM & 0.707 \\
\hline \multirow{2}{*}{ Value of Company } & TOBIN Q. & 0.709 \\
\hline & PER & 0.709 \\
\hline
\end{tabular}

Dividend policy is reflected in the two indicators, i.e. dividend yield and dividend payout ratio. The development of dividend yield and dividend payout ratio average is reflected in Figure 2 below.

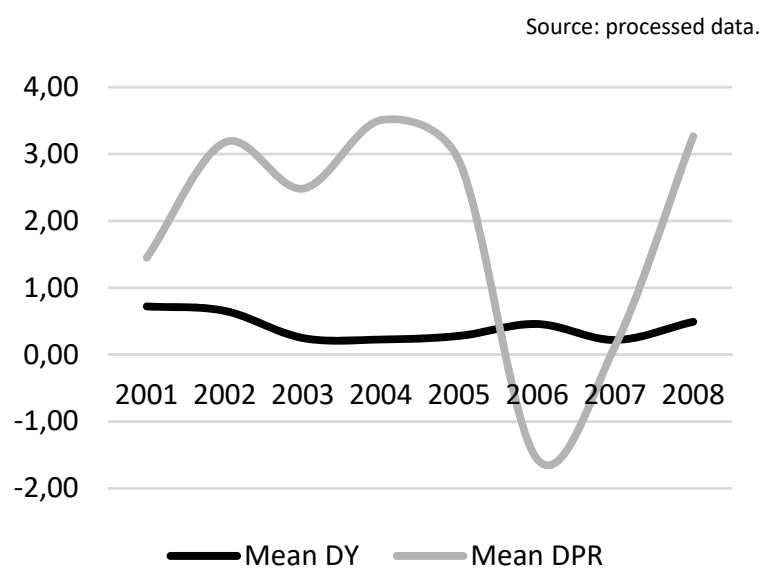

Figure 2. Development of Average. Average Value Indicator policy Sector Dividend Property and Real Estate during 2001-2008 
The percentage of the highest average value of Dividend Payout Ratio in the year was 0.03266 time from the revenue of shares per page. Based on Figure 2. the percentage of descriptive results of Dividend Payout Ratio, it seems to be a trend of companies to keep paying dividend even though they suffered a loss on the year. It can be seen from the average in every year. The dividends are always paid where there are fluctuations in dividend payments, the payments are in accordance with the level of profits obtained in the year concerned.

Based on the results of descriptive statistics, investment decision is a latent variable measured using four indicators, i.e. Market to Book Asset Ratio (MBAR), Capital Expenditure to Book Value Asset (CAP/BVA), Current Asset to Total Asset Ratio (CATAR), Market to Book Value Equity (MBVE). The description results of each indicator can be seen in Figure 3 below:

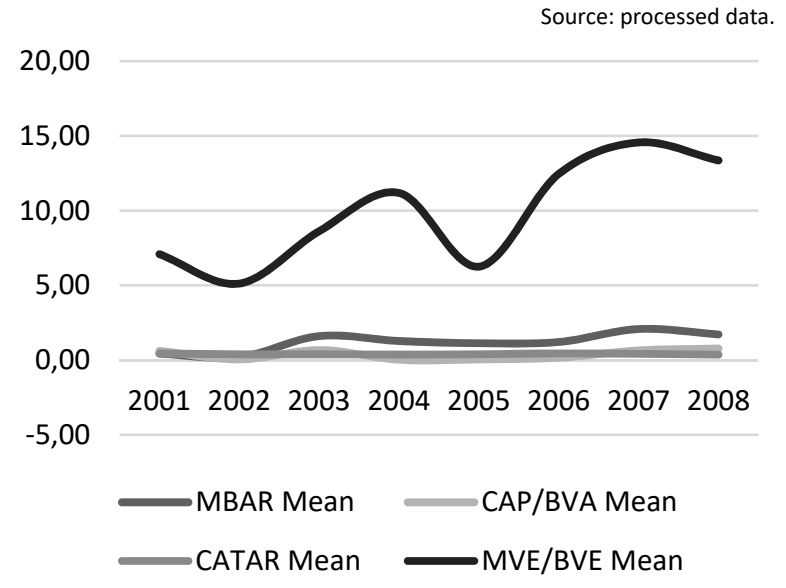

Figure 3. Development of Average. Average Value Indicators of Investment Decision in Property and Real Estate Sector during 2001-2008

Based on the figure, Market to Book Ratio Asset shows the ratio of market value of equity on book value of asset. The market value of equity depends on the stock price. If the stock price increases, then the market value of asset also increases because of the increase in equity value. The average ratio of the market value of equity on asset value in the sectors of property and real estate since 2001 fluctuated, where the ratio of the average market value of equity on the lowest asset value was 0.20 in 2002. Meaning that in that year, the market value of asset compared to the book value was far below the book value of asset. While in 2007 the highest average market value of the asset was 2.08 , which means that the average market value of asset was more than double of the book value. The average market value of equity tends to rise since 2002 until 2007, while decreased in 2008. The market value of equity in the sectors of property and real estate is very sensitive to economic conditions, i.e. macroeconomic conditions, in accordance with Husnan (2005) who suggests that in accordance with the business cycle, the sectors of property and real estate are very sensitive to economic conditions, especially economic growth, inflation, and the interest rates. This was confirmed with the survey conducted by Wuryadani, Hermanto, Prasetya (2005) which states that the developer and consumer perceptions about the prospect for the property industry is based on developments in economy, social, political conditions, and security as well as the movement of interest rates. While Saleh et al. (2011) state that the potential development of the property business in Indonesia is very large. The important factors underlie this potential show, a very positive signal from the stable economic and political situation, an increase in GDP and demand for property as well as the decrease levels of poverty and unemployment.

Descriptive analysis results of financing decision in the form of latent variables (unobserved variables) with indicators to measure. There are five indicators of financing decisions, i.e. Long Term Debt to Equity (LTDE), Debt to Market Equity (DTME), Debt to Total Asset (DTA), Short Term Debt to Book Value (SDTBV), Retained Earning (RE). So, on the following description, each indicator is described descriptively in Figure $4(a, b)$.

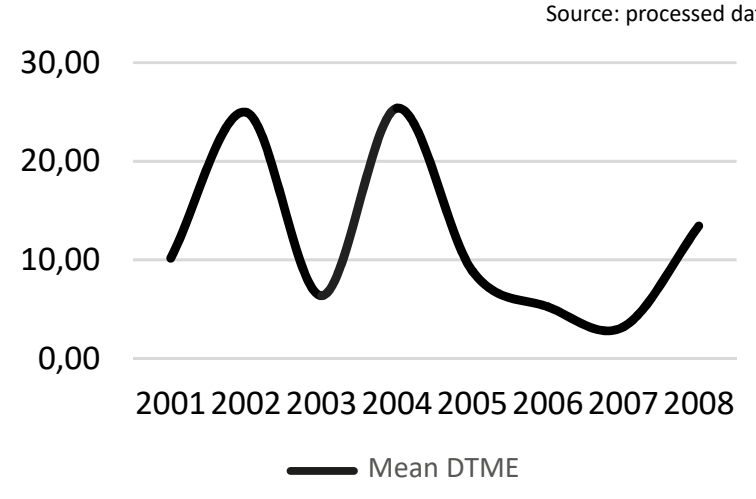

Figure 4a. Development of Average. Average Value Indicators of Decision Funding in the Property and Real Estate Sector during 2001-2008 
6

4

2

0

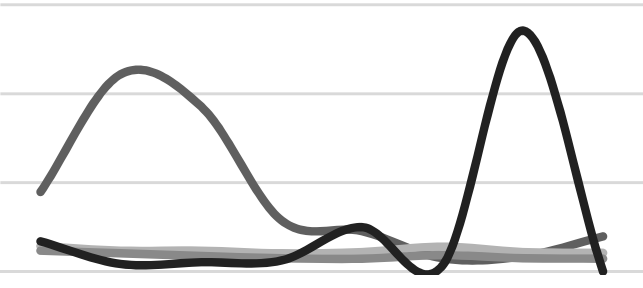

20012002200320042005200620072008

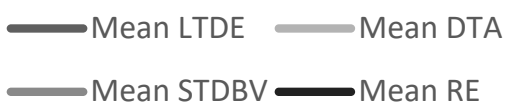

Figure 4b. Development of Average. Average Value Indicators of Decision Funding in the Property and Real Estate Sector during 2001-2008

The low average of LTDE in 2006 can not be separated from Indonesia's economy in the previous years, i.e. 2002 to 2005, when the interest rate (SBI) decreased and the rate of economic growth increased. These conditions resulted in revenues increased, and ability to pay long-term debt also increased, and subsequently the debt value in 2006 decreased. The smaller the long-term debt, the smaller the debt interest expense to pay and the more able the companies to meet their long-term liabilities and the smaller the risk of the companies not to pay their debt so that the corporate value can increase.

The average debt of companies in the sectors of property and real estate on the market value is quite varied, where the lowest average value occurred in 2007 was 3.2006 and the highest average value in 2004 was 25.3898 , means that there was a higher debt burden than the market value of equity. The higher this ratio, the greater the debt that is secured by asset and the greater the risk that arises due to the amount of interest expense that must be paid and the corporate value will decrease. The high proportion of debt in 2001 was caused by the economy that is still recovering wherein the sectors of property, and real estate growth is still slow and interest rates that are still high. Consequently, the public interest to invest in the sectors of property and real estate is still low, so that the company's ability to pay debts is still limited.

The average ratio value of short-term debt on book value of total assets fluctuate, which the lowest ratio value of short-term debt on total assets was 0.29 in 2008, which means that $29 \%$ of short-term debt was guaranteed by total assets. While the high- est ratio value of short-term debt was 0.47 in 2001, means short-term debt in 2001 was $47 \%$ of the total assets. The lowest average value of retained earning growth was 0.003 in 2008, while the highest average value of retained earning growth occurred in 2007 was 5.42. The high retained earning growth was due to the increased level of economic growth in Indonesia and declined interest rates, leading to the increased sales on the property and real estate, so that revenues also increased. Although in 2008, there was a decrease in retained earning growth due to the global crisis impact in which the production cost increased, so that the level of profits decreased.

The corporate value in this study was measured using indicators of Tobin Q, Price Earning Ratio (PER) and Stock Price. For the detail, please see in Figure 5.

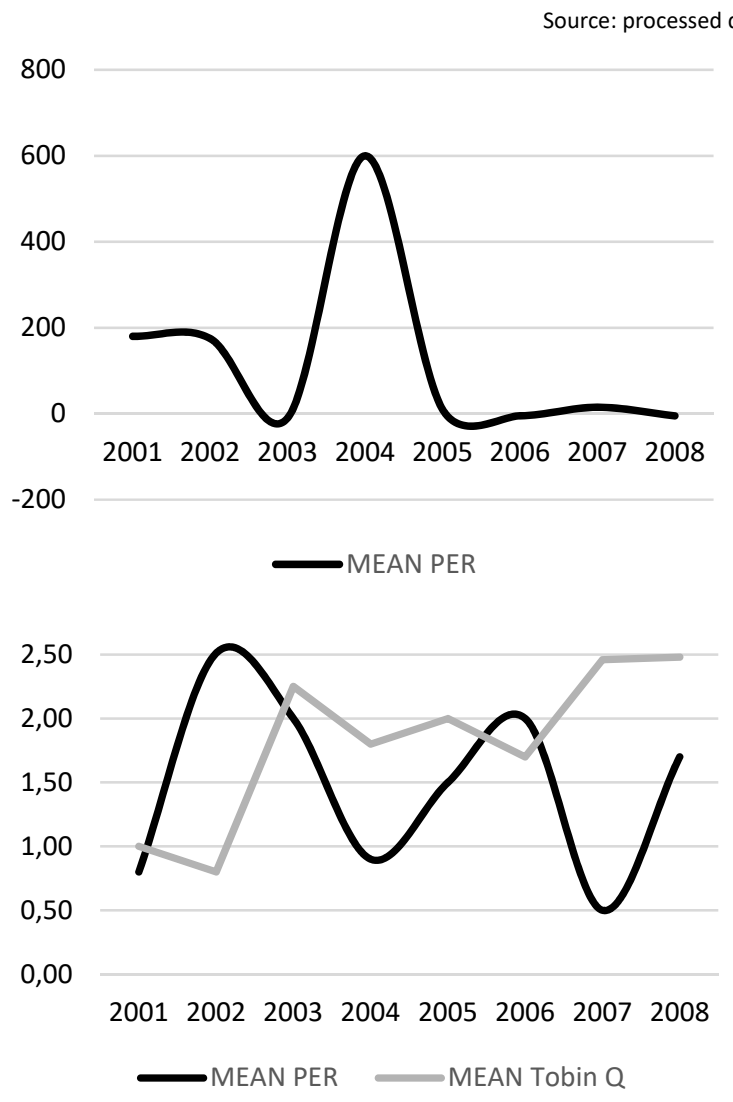

Figure 5. Development of Average. Average Value of Companies in Sector. Indicator Value in

Property and Real Estate during 2001-2008

Figure 5 shows that Tobin Q value with the average that is relatively low in 2002 and 2003, when the Tobin Q value was 0.84 then increased to 2.26 . 
The highest average Tobin $Q$ value was 2.64 in 2008, while the lowest was 0.84 in 2002 . In terms of descriptive results in Figure 5, it appears that the lowest value $<1$, means that the market value of the company is reflected in the market value of equity plus debt lower on the ratio value based on book value. This may imply that there was a decline in market value of equity in 2002 resulting from the decline in stock price in the sectors of property and real estate. The decrease in the performance of the sectors of property and real estate was due to the decline in the rental price of property and real estate and will certainly affect the decrease of market price of equity of shares in the sectors of property and real estate.

Testing Goodness of Fit uses predictive value-relevance (Q2). The value of $\mathrm{R}_{2}$ of each endogenous variable in this study is as follows: 1) for variable Investment Decision acquired $\mathrm{R}_{2} 0.204$; 2) for variable Funding Decisions obtained $\mathrm{R}_{2}$ of 0.209 ; and 3) for the Company's variable value obtained $R_{2}$ value of 0.505 . Predictive value-relevance is obtained by the formula:

$$
\begin{aligned}
Q^{2} & =1-\left(1-R_{1}^{2}\right) \cdot\left(1-R_{2}^{2}\right) \cdot\left(1-R_{3}^{2}\right) \ldots\left(1-R_{p}^{2}\right), \\
Q^{2} & =1-(1-0.204) \cdot(1-0.209) \cdot(1-0.505)= \\
& =0.6883=68.83 \% .
\end{aligned}
$$

The calculation result showed predictive valuerelevance of 0.6883 , or $68.83 \%$, making it feasible models are said to have predictive value relevant. Relevance of predictive value of $68.83 \%$ indicates that the diversity of data that can be explained by the model is equal to $68.83 \%$, or in other words, the information contained in the data (68.83\%) can be explained by the model. While the remaining $31.17 \%$ is explained by other variables (which is not contained in the model) and error.

Hypothesis testing is performed on each track, which directs effect partially. Detailed results of the analysis, contained in WarpPLS analysis results, can be seen in Table 2 . The following table presents the results of testing direct influence hypothesis.

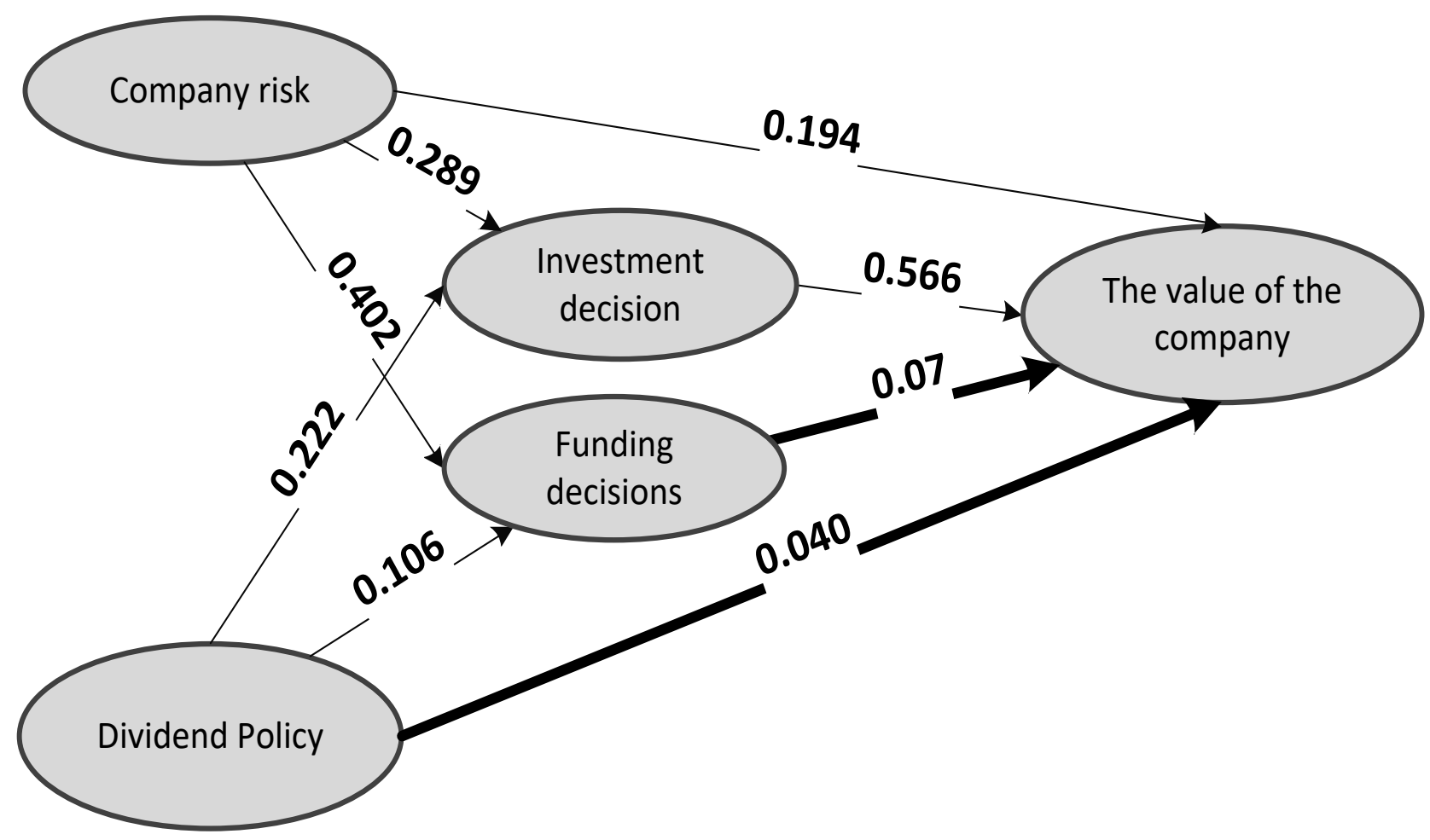

Figure 6. Effect of Risk Analysis Results in WarpPLS Dividend Policy of the Company and Investment Decisions, Decisions Funding to Company Value 
Table 2. Hypotheses Testing Model WarpPLS

\begin{tabular}{|c|c|c|c|}
\hline Relationship & Coefficient Path & p-value & Conclusion \\
\hline Company risk $\rightarrow$ Investment decision & 0.289 & $<0.001$ & Significant \\
\hline Devidend Policy $\rightarrow$ Investment decision & 0.222 & $<0.001$ & Significant \\
\hline Company risk $\rightarrow$ Funding decisions & 0.402 & $<0.001$ & Significant \\
\hline Dividend Policy $\rightarrow$ Funding decisions & 0.106 & 0.045 & Significant \\
\hline $\begin{array}{l}\text { Investment decision } \rightarrow \text { The value of the } \\
\text { company }\end{array}$ & 0.566 & $<0.001$ & Significant \\
\hline $\begin{array}{l}\text { Funding decisions } \rightarrow \text { The value of the } \\
\text { company }\end{array}$ & 0.070 & 0.132 & Not Significant \\
\hline $\begin{array}{l}\text { Company risk } \rightarrow \text { The value of the } \\
\text { company }\end{array}$ & 0.194 & $<0.001$ & Significant \\
\hline $\begin{array}{l}\text { Dividend Policy } \rightarrow \text { The value of the } \\
\text { company }\end{array}$ & 0.040 & 0.263 & Not Significant \\
\hline
\end{tabular}

Table 3. The results of Hypotheses Testing in Inner Model: Indirect Influence

\begin{tabular}{|c|c|c|c|}
\hline Indirect influence & \multicolumn{2}{|c|}{ Coefficient of direct impact } & Coefficient of indirect \\
\hline $\begin{array}{l}\text { Company risk } \rightarrow \text { Investment decision } \\
\rightarrow \text { The value of the company }\end{array}$ & $\begin{array}{l}\text { Company risk } \\
\rightarrow \text { Investment decision } \\
\left(0.289^{*}\right)\end{array}$ & $\begin{array}{l}\text { Investment decision } \\
\rightarrow \text { The value of the } \\
\text { company }\left(0.566^{*}\right)\end{array}$ & $0.164^{*}$ \\
\hline $\begin{array}{l}\text { Dividend Policy } \rightarrow \text { Investment decision } \\
\rightarrow \text { The value of the company }\end{array}$ & $\begin{array}{l}\text { Dividend Policy } \\
\rightarrow \text { Investment decision } \\
(0.222)\end{array}$ & $\begin{array}{l}\text { Investment decision } \\
\rightarrow \text { The value of the } \\
\text { company }\left(0.566^{*}\right)\end{array}$ & $0.126^{*}$ \\
\hline $\begin{array}{l}\text { Company risk } \rightarrow \text { Funding decisions } \\
\rightarrow \text { The value of the company }\end{array}$ & $\begin{array}{l}\text { Company risk } \\
\rightarrow \text { Funding decisions } \\
\left(0.402^{*}\right)\end{array}$ & $\begin{array}{l}\text { Investment decision } \\
\rightarrow \text { The value of the } \\
\text { company }(0.070)\end{array}$ & 0.028 \\
\hline $\begin{array}{l}\text { Dividend Policy } \rightarrow \text { Funding decisions } \\
\rightarrow \text { The value of the company }\end{array}$ & $\begin{array}{l}\text { Dividend Policy } \\
\rightarrow \text { Funding decisions } \\
\left(0.106^{*}\right)\end{array}$ & $\begin{array}{l}\text { Investment decision } \\
\rightarrow \text { The value of the } \\
\text { company }(0.070)\end{array}$ & 0.007 \\
\hline
\end{tabular}

Note: * significant

From the test of direct effect between coefficient value was obtained, with $p$-value $<0.001$. Because p-value $<0.05$, then there was a significant direct effect between the Corporate Risk on Investment Decisions. Given the inner weight coefficient was positive, it was indicating that their relationship was unidirectional. Thus, the higher the Corporate Risk, the higher the Investment Decisions.

The Dividend Policy level will not result in a change in the Corporate Value. In addition to testing the direct effect, on WarpPLS also known as indirect effect (indirect effect). The indirect effect is the result of multiplying two (2) indirect influence. The indirect effect is declared significant if both the direct influence, which that shape is significant. Here is presented the results of the indirect effect:

From the indirect (mediating) effect between the Corporate Risk on Corporate Value through Investment Decisions, indirect effect coefficient of 0.164 was obtained. Because the direct effect of the Corporate Risk on Investment Decisions of 0.289 and the Investment Decisions on Corporate Value of 0.566 were both significant, there was a significant indirect effect between the Corporate Risk on Corporate Value through Investment Decisions. With a positive coefficient, it showed a directly pro- 
portional relationship. It showed that the higher the Corporate Risk, the more increasing the Corporate Value, but if the Investment Decisions get higher.

From the indirect (mediating) effect between Dividend Policy on Corporate Value through the Investment Decisions, the indirect effect coefficient of 0.126 was obtained. Because the direct effect of Dividend Policy on Investment Decisions of 0.222 and Investment Decisions on Corporate Value of 0.566 were both significant, there was a significant indirect effect between Dividend Policy on Corporate Value through Investment Decisions. With a positive coefficient, it showed a directly proportional relationship. It showed that the higher the Dividend Policy, the higher the Corporate Value, but if the Investment Decisions get higher.

From the indirect (mediating) effect between the Corporate Risk on Corporate Value through Financing Decisions, the indirect effect coefficient of 0.028 was obtained. Because the direct effect of Corporate Risk on Financing Decisions of 0.402 was significant and Financing Decision on Corporate Value of 0.070 was not significant, there was no significant indirect effect between the Corporate Risk on Corporate Value through Financing Decisions. It indicated that the level of the Corporate Risk will have no impact on the Corporate Value level, although Funding Decisions experience changes.

From the indirect (mediating) effect between the Dividend Policy on Corporate Value through Financing Decisions, the indirect effect coefficient of 0.007 was obtained. Because the direct effect of Dividend Policy on Financing Decisions of 0.106 was significant and Financing Decisions on Corporate Value of 0.070 was not significant, there was no significant indirect effect between Dividend Policy on Corporate Value through Financing Decisions. It indicated that Dividend Policy level would not affect the Corporate Value level, although Financing Decisions experienced changes.

\section{DISCUSSION}

Based on the research findings, investment decisions had a significant direct impact on the corporate value. The findings are consistent with the hypothesis stating that investment decisions have a significant positive effect on the corporate value in which the right investment decision will improve the corporate value. These findings imply that a good investment decision is an investment decision that can generate a positive NPV, meaning that the investment decision can generate a higher return than the capital cost incurred by the company.

In accordance with the investment theory states that any investment decision made is expected to produce the rate of return with a particular risk with the assumption that individuals are rational and do not like risk. According to Table 2, corporate value always increases with the increased investment value. Yet, there was an important note about investors behavior in investment decisions in 2004 with the general election. There was a decrease in the investment value but also impacted on the decrease in the corporate value. A very large decrease in the investment value on that year occured as the investors refrained for a while not to invest until political conditions were safe.

Based on the research findings, financing decisions had no direct significant effect on the corporate value. These research findings are not consistent to hypothesis $\mathrm{H}_{2}$ a stating that financing decisions have a significant effect on corporate value. There were two MM capital structure theories used in this study, i.e. MM capital structure irrelevance theory (without taxes) and capital structure theory with taxes.

Based on the MM theory without taxes stating that capital structure has no effect on the corporate value by assuming the company has the same business risk, all investors and potential investors have the same estimation on the company's future EBIT and stocks and bonds traded in the perfect capital market. The weakness of this theory is unrealized assumption of perfect market. In fact, perfect market in the world does not exist and the assumption of that the investors have the same assumption on EBIT in the future cannot be realized since not all potential investors have the same estimation on EBIT in the future.

MM theory with taxes states that the capital structure affects the corporate value by consider- 
ing the company's tax and personal tax. MM theory states that the increase in debt would increase the corporate value due to the tax savings. Yet, the weakness of this theory is it does not consider the costs resulting from debt, in the form of agency costs and bankruptcy costs.

Based on the research findings, it was found that the risk had a significant positive effect on corpo- rate value. The findings are consistent with the hypothesis stating that the risk has a significant effect on the corporate value. This positive coefficient indicates the increased risk will result in the increase in the corporate value. This is contrary to trade-off theory stating that the greater the debt, the greater the risk of bankruptcy which would be borne by the company, which will cause the corporate value decreases.

\section{CONCLUSION AND RECOMMENDATIONS}

\section{Based on the results, it can be summed up as follows:}

1. Changes in the pattern of financing investment in the company - the company sector of the property and real estate were originally sourced from borrowing short-term funds from abroad and are now sourced from selling products preselling and own capital derived from internal sources can improve the investment decisions made by the company become better and can increase the value of the company. Because investment decisions being taken are no buyers so that the present value of cash inflows from its income to certain, so the risk of the company arising from investment decisions will affect the value of company in property sector - the company sector of the property and real estate for investment made by company - company property and real estate sector has been secured by the proceedings from the preselling so that the risk of unsold product to be low. This fact indicates that the property companies and real estate validity of the theory of risk and return proved for investments made guarantees to the buyer and the financing of these investments sourced from its own capital and preselling of the debt so that the company's risk to be small and the value of the company be increased.

2. The decision on funding is not able to increase the value of the company. Further funding decisions that could either mean that the decision could produce greater benefits than the losses incurred due to the decision to increase the value of the company. On property companies and real estate after the post-crisis changes in funding patterns of the use of short-term debt into capital usage of own and preselling and selling products aimed at reducing risks that arise and be able to enhance shareholder value. This research is the development of theory and MM theory of capital structure with taxes on company property and real estate sector in the Indonesia Stock Exchange.

3. The dividend policy is not able to increase the value of the company at the company - the company property and real estate sector well. This is due to that the present value of future cash flows (dividends and capital gains) remain the same. In other words, the dividend policy is only to change the timing of dividend payments, such that the total cash flow to be received in the future will remain the same. Besides, the company's property and real estate sectors were mostly owned by the institution or holding and family so that the dividend payment will have no impact on the company's risk. This is due to dividend payments adjusted for gains at the time. Besides that investors in the property sector do not see dividend payments an important matter in the increased value of the company, the investors look mainly at the prospects and future growth of the company, which means that in this study it is found that the theory of Bird in Hand and signaling theory is not proven. The study found that the increased risk in the company - the company property and real estate sectors were able to increase the value of companies on the contrary to decreased risk of causing the value of the company down. 


\section{Based on the results of research and discussion such suggestions can be put forward:}

1. Funding decisions must be taken into consideration for the companies in the sectors of property and real estate in investment. An error in the determination of the financing decisions will result in an increase in the corporate risk in investment, so that the increase in risk will affect the corporate value.

2. The study was conducted at the companies in the sectors of property and real estate, then this study better developed for other sectors that have different characteristics.

3. Further researches should include macroeconomic variables, such as economic growth, exchange rates, inflation and interest rates as material considerations in the determination of the corporate risk directly, so that the impacts of economic growth, changes in exchange rates, inflation and interest rates can be analyzed directly on the corporate value.

\section{REFERENCES}

1. Damodaran, Aswath. (2006). Damodaran on Valuation, Security Analysis for Investment and Corporate Finance, Edisi kedua, John Willey \& Son, Inc., New Jersey, USA.

2. Fama, E. F. (1978). The Effects of a Firm's Investment and Financing Decisions on the Welfare of its Security Holders. The Modern Theory Of Corporate Finance, 68(3), 22-38.

3. Gitman, Lawrence J. (2003). Principles of Managerial Finance. International Edition, 10th edition, Pearson Education, Boston.

4. Hanafi, M. Mahmud and Abdul Halim. (2005). Financial Statement Analysis (in Indonesia: Analisi Laporan Keuangan), Second Edition. AMP. YKPN. Yogyakarta.

5. Handaka. (2008). Jakarta property Unaffected global crisis. (in Indonesia: Properti Jakarta Tak Terpengaruh Krisis Global). Harian Kompas.

6. Husnan, Suad. (2000). The Theory and Application of Financial Management (in Indonesia: Manajemen Keuangan Teori dan Penerapan), Third Edition. Yogyakarta: UPP AMP YKPN.

7. Jensen, M. C. (2001). Value Maximization, Stakeholders Theory, and The Corporate Objective Function. Working Paper, No. 01-09. Harvard Business School, 1-21. Retrieved from www.google.com/ search/Working Paper/Harvard Business School
8. Martono, Agus (2001). Financial Management (in Indonesia: Manajemen Keuangan), Faculty of Economics, University of Indonesia, Jakarta.

9. Masdar Mas'ud. (2008). Analysis of Factors - Factors Affecting Capital Structure and Its Relationship to the Company Values (in Indonesia: Analisis Faktor - faktor yang Mempengaruhi Struktur Modal dan Hubungannya terhadap Nilai Perusahaan). Journal of Management and Business, 7(1), March 2008, Fe Universitas Muslim Indonesia.

10. Muslimin. (2006). Analysis of Ownership Structure, Corporate Growth and External Factors of the Company Values (in Indonesia: Analisis Struktur Kepemilikan, Pertumbuhan Perusahaan dan Faktor Ekstern terhadap Nilai Perusahaan). Dissertation. Universitas Brawijaya, Malang.

11. Nurdin. (1999). Analysis of Effects of Inflation, Exchange Rate, Interest Rate, Economic Growth, Government Policy, Capital Structure, Asset Structure, Liquidity against investment risk Property stocks in the Jakarta Stock Exchange. Thesis Master of Management Universitas Diponegoro. (Unpublished).

12. Riyanto, Bambang. (2001). Basics of Company Spending (in Indonesia: Dasar-Dasar Pembelanjaan Perusahaan), Fourth Edition, Seventh Moulds, BPFE Yogyakarta, Yogyakarta.
13. Ross, S. A., Westerfield, R. W., Jaffe J., (2005). Corporate Finance. 7th Ed., McGrawHill Companies, Inc., New York.

14. Saleh, M., Zulkifli, N. \& Muhamad, R. (2011). Looking for Evidence of the Relationship between Corporate Social Responsibility and Corporate Financial Performance in an Emerging Market. Asia - Pacific Journal of Business Administration, 3(2), 165.

15. Sudarma, Made. (2004). Effect of Shareholding Structure, Factor Against Internal and External Factors of Capital Structure and Firm Value (Studies in Industrial GoPublic in Jakarta Stock Exchange), Dissertation Postgraduate Program of Brawijaya University, Malang.

16. Van Horne, James C. (2002). Financial Management and Policy. 12th Edition, Prentice Hall International, Inc., New Jersey.

17. Wasnieski. (2008). Corporate Risk and Shareholder Value. Retreived from https://papers.ssrn.com/sol3/ papers.cfm?abstract_id $=1117247$ Accessed on March 292009.

18. Wijanarko, Hendro. (2008). Funding Policy Analysis Company And Its Effect on Firm Value (Study On Manufacturing Sector Companies Listed on the Stock Exchange). Dissertation, University of Brawijaya. 